\title{
Assessment of wild tomato accessions for fruit yield, physicochemical and nutritional properties under a rain forest agro-ecology
}

\author{
Dorcas O. Ibitoye $^{\mathrm{a}}$, Adesike O. Kolawole ${ }^{*, \mathrm{~b}}$ and Roseline T. Feyisola ${ }^{\mathrm{c}}$ \\ ${ }^{a}$ Genetic Resources Unit, National Horticultural Research Institute, PMB 5432, Ibadan, Nigeria \\ ${ }^{b}$ Department of Crop Production and Soil Science, Ladoke Akintola University of Technology, PMB 4000, Ogbomoso, \\ Nigeria \\ ${ }^{c}$ Department of Plant Science, Olabisi Onabanjo University, Ago-Iwoye, Nigeria
}

\begin{abstract}
Tomato (Solanum lycopersicum L.) is a broadly consumed fruit vegetable globally. It is one of the research mandate vegetable of the National Horticultural Research Institute (NIHORT), Ibadan, Nigeria. The institute's genebank contains diverse collections of tomato accessions and wild relatives, without utilization information for the African continent. With the decline in diversity and potential of cultivars, a robust tomato breeding pipeline with broad genetic base that eliminates redundancy in the development of lines with desired horticultural traits is paramount. This study evaluated the mean performance and variations of thirteen wild tomato accessions obtained from the C.M. Rick Tomato Genetic Resource Center, University of California, Davis, USA, evaluated for agronomic, nutritional and physicochemical traits under a rain forest agro-ecology zone in Nigeria. The accessions were planted and grown in three replications with randomized complete block design. Agronomic traits, physicochemical and nutritional parameters were measured and analyzed. There was significant (P $<0.001$ ) variation among accessions for all traits measured. Accession LA0130 was separated from others by cluster analysis and was outstanding for its unique attributes which include: fruit yield parameters, total soluble solids, titratable acidity and lycopene content. The principal component analysis suggests fruit yield related traits, titratable acidity and lycopene contributed most to the variation among the 13 accessions. The results obtained can be used to breed materials adapted to a rain forest agro-ecology. These wild tomato accessions have genes with desirable agronomic, nutritional and physicochemical traits that could be introgressed into breeding lines to improve commercial tomato varieties.
\end{abstract}

Keywords: agronomic traits, breeding programme, fruit quality, variation, wild relatives

Citation: Ibitoye, D. O., Kolawole, A. O., Feyisola, R. T. (2020). Assessment of wild tomato accessions for fruit yield, physicochemical and nutritional properties under a rain forest agro-ecology. Genetic Resources 1 (2), 1-11. doi: 10.46265/genresj.BJCV8100.

(C) Copyright 2020 the Authors.

This is an open access article distributed under the terms of the Creative Commons Attribution License (CC BY 4.0), which permits unrestricted use, distribution, and reproduction in any medium, provided the original author and source are credited.

\section{Introduction}

Tomato (Solanum lycopersicum L. formerly Lycopersicon esculentum Mill.) is one of the most famous and broadly consumed vegetable crops throughout the world (Nowicki et al, 2013; Ajayi and Hassan, 2019). Nigeria was ranked the largest producer of tomato in West Africa and the $16^{\text {th }}$ largest producer in the World with 4.2 million metric tonnes FAO (2016).

${ }^{*}$ Corresponding author: Adesike O. Kolawole

(aokolawole@lautech.edu.ng)
These data suggest prospects for Nigeria tomato breeding programmes to enhance production efficiency by improving the quantity and quality of tomato fruit. However, extensive breeding efforts and selection over the years have modified tomato (Blanca et al, 2015). The decline in diversity and potential of cultivated germplasm has been reported (Jatoi et al, 2008; Chen et al, 2009). To enlarge the gene pool of cultivars, breeders now focus on introgression of desirable genes from wild relatives (Singh, 2006) .

Wild tomato species have a rich reservoir of useful genetic traits needed to improve cultivated toma- 
toes and serve as sources of genetic variability (Hanson et al, 2007). Miller and Tanksley (1990) reported that the genomes of cultivated tomato contain $5 \%$ of the genetic variation of their wild relatives. These wild tomato species are native to western South America and distributed from central Ecuador, through Peru to northern Chile, and in the Galápagos Islands (Darwin et al, 2003). There are 16 wild species of tomato, namely Solanum habrochaites, S. pennellii, S. pimpinellifolium, S. cheesmaniae, S. galapagense, S. peruvianum, S. corneliomulleri, $S$. chilense, $S$. chmielewskii, $S$. arcanum, $S$. neorickii, S. huaylasense, S. lycopersicoides, S. ochranthum, S. jugandifolium, and S. sitiens (Rick and Fobes, 1975; Peralta et al, 2008; Zuriaga et al, 2009). The closest wild ancestor to cultivated tomato is $S$. pimpinellifolium L. found in the centre of origin of tomato from the northern part of Chile to Colombia. Most of these wild relatives are vulnerable to extinction because of their small population sizes (Bai and Lindhout, 2007; Onyia et al, 2019). Therefore, wild tomato accessions stored in genebanks need to be evaluated in time and space in order to identify significant traits and valuable potential. Documented information about the performance of wild tomato accessions will aid future use in tomato breeding programmes.

Currently, the breeding programme at the National Horticultural Research Institute (NIHORT), Ibadan, Nigeria has made diverse collections of landraces, cultivars and wild tomato accessions. Only the landraces and cultivars have been extensively studied for their agronomic performance and resistance to abiotic and biotic stresses (Olaniyi et al, 2010; Nnabude et al, 2015). However, the wild accessions obtained from the C.M. Rick Tomato Genetic Resource centre, University of California, Davis, USA have not been studied for the identification of useful agronomical traits, nutritional and physicochemical parameters in Nigeria.

In addition to fruit yield and improved agronomical traits, the fruit quality and nutritional parameters are essential breeding objectives from a consumer's point of view and even in the processing industries (Bauchet and Causse, 2012; Bergougnoux, 2014). Fruit quality and physicochemical parameters are cultivar dependent (Riahi et al, 2009; Ilahy et al, 2011; Domínguez et al, 2012). Fertilization, cultural practices and postharvest storage could influence fruit quality and physicochemical parameters (Rosales et al, 2011; Beckles, 2012). Production of quality tomato fruits depends on the climatic conditions, sunlight availability, good agronomic practices and genetic variability among cultivars (Causse et al, 2003; Peixoto et al, 2018).

In order to identify, select and develop novel tomato lines with desired horticultural traits for a Nigerian breeding programme, it is crucial to evaluate tomato accessions which are wild to the Nigerian germplasm. These could then be subjected to diverse breeding methodologies and agronomic practices (Chitarra and Chitarra, 2005). Knowledge of desirable traits from the evaluated tomato accessions will help to identify those that could be used as parents in a tomato breeding programme, hence, promoting improved nutrition and increased production (Causse et al, 2003; Álvaro Toledo and Burlingame, 2006).

This study evaluated mean performance and variation among wild tomato accessions based on agronomic, nutritional and physicochemical traits under rainforest agro-ecology in Nigeria.

\section{Materials and Methods}

\section{Germplasm}

The accessions evaluated in this study are from the C.M. Rick Tomato Genetic Resource Centre (TGRC), University of California, Davis, USA (Table 1). They are part of the tomato wild relatives core collection of the NIHORT germplasm bank without previous utilization information that could be included in breeding programmes.

\section{Nursery and field operations}

Seeds were sown into perforated nursery trays filled with sterilized soil and grown for three weeks in a greenhouse at NIHORT, Ibadan, Oyo State (Rain forest zone; $3^{\circ} 56^{\prime} \mathrm{E}, 7^{\circ} 33^{\prime} \mathrm{N}$; 168 meters above sea level). The perforated nursery trays were kept moist by regular watering on daily basis at sunrise and sunset with tap water using a watering can. Seedlings were transplanted to the field in paired rows in plots that were $2 \mathrm{~m}$ long with spacing of $0.5 \mathrm{~m}$ between rows and $0.5 \mathrm{~m}$ between plants within a row. Spacing between plots was $1 \mathrm{~m}$. Seedlings were arranged in a randomized complete block design with three replications. N-P-K (15-15-15) fertilizer was applied at the rate of $120 \mathrm{~kg} / \mathrm{ha}$ three weeks after transplanting. The plants were trellised to prevent lodging and loss of fruits due to diseases and pests. Manual weeding was carried out at two-week intervals. To protect the leaves from defoliating pests, plants were sprayed with the pyrethroid insecticide Cymbush containing cypermethrin at 2, 6, and 9 weeks after transplanting at the rate of $450 \mathrm{ml}$ of active ingredients per 100 liters of water per hectare using a knapsack sprayer. No disease infestation was observed during the experiment and data were collected on five randomly selected plants per plot.

\section{Sample preparation}

Uniformly ripe, healthy fruit at the red-ripe stage were harvested (Hanson et al, 2004). A total of 1015 representative fruit were collected from pre-tagged plants (from the first 3 clusters) to minimise intra-plant variability (Borja et al, 1998). Tomato samples (100 g) were homogenized in $50 \mathrm{~mL}$ of water in a water bath at $4^{\circ} \mathrm{C}$ and low light (to reduce antioxidant loss) for physicochemical analysis. All analyses were done in triplicate for each sample at the Product Development Laboratory of NIHORT. 
Table 1. Description of the 13 species of wild tomato accessions used for the experiment

\begin{tabular}{llll}
\hline No. & Accession ID & Species & Origin (Area of collection) \\
\hline 1 & LA0103 & Solanum peruvianum (L.) Miller & Cajamarquilla Lima, Peru \\
2 & LA0130 & Solanum chilense Dunal & Moquegua, Peru \\
3 & LA0411 & Solanum pimpinellifolium (L.) Miller. & Pichilingue, Los Rios, Ecuador \\
4 & LA1028 & Solanum chmielewskii (C.M. Rick et al.) & Casinchichua, Apurimac, Peru \\
5 & LA1041 & Solanum cheesmanii L. Riley & Santa Cruz, El Cascajo, Galapagos \\
& & & Islands, Ecuador \\
6 & LA1136 & Solanum cheesmanii L. Riley & Gardner st, Floreana Islet, Galapagos \\
7 & LA1208 & Solanum esculentum var. cerasiforme Dunal & Islands, Ecuador \\
8 & LA1272 & Solanum pennellii (Correll) D'Arcy & Sierra Nevada, Colombia \\
9 & LA1293 & Solanum peruvianum f. glandulosum (C.F. Mull) & Pesquera, Lima, Peru \\
10 & LA2641 & Solanum parviflorum (C.M. Rick et al.) & Apurimac, Peru \\
11 & LA4113 & Solanum sitiens I.M. Johnst. & Estación Ceres, Antofagasta Chile \\
12 & LA4115 & Solanum sitiens I.M. Johnst. & Quebrada Desde Cerro, Oeste De Paqui, \\
& & & Antofagasta, Chile \\
13 & LA4138 & Solanum pimpinellifolium (L.) Miller & El Corregidor, La Molina, Lima, Peru \\
\hline
\end{tabular}

\section{Physicochemical and nutritional analyses}

Total soluble solid ( ${ }^{\circ}$ Brix) (g $100 \mathrm{~g}^{-1}$ ) of the juice was measured using the Eclipse hand-held refractometer $\left[\mathrm{PN} \#\right.$ 45-01 (0-15 ${ }^{\circ}$ Brix $\left.)\right]$ and the $\mathrm{pH}$ of the fruit juice was measured using a benchtop $\mathrm{pH}$ meter (Sper scientific benchtop) with the $\mathrm{pH}$ meter calibrated with standard buffers $\mathrm{pH} 4$ or 9. For determination of titratable acidity (g $100 \mathrm{~g}^{-1}$ ) and vitamin C content (mg $100 \mathrm{~g}^{-1}$ ), $10 \mathrm{~mL}$ of juice from 10 fruits was diluted in $100 \mathrm{~mL}$ of distilled water and titrated with $\mathrm{NaOH}(0.1 \mathrm{~N})$ to $\mathrm{pH}$ 8.2. For vitamin $\mathrm{C}$, the solution was titrated with iodine $(0.1 \mathrm{~N})$ until a colour change was observed (International Plant Genetic Resources Institute, 1996) .

To determine lycopene content (mg $100 \mathrm{~g}^{-1}$ ), $5 \mathrm{~mL}$ of acetone-n-hexane mixture in the ratio $4: 6$ was added to $0.8 \mathrm{~g}$ of tomato pulp for each sample and mixed well. The mix was centrifuged at $5000 \mathrm{rpm}$ for $5 \mathrm{~min}$ at $4^{\circ} \mathrm{C}$; the supernatant was extracted and absorbance measured with a spectrophotometer (model 6400, Jenway) at 503 $\mathrm{nm}$ using the acetone-n-hexane mix as blank (Rosales et al, 2006). Lycopene content was calculated using an extinction coefficient $\left(E^{\%}\right)$ of 3150 .

\section{Agronomic data collection}

Data were collected on the following traits: number of leaves at maturity (NLM), plant height at maturity (PH), number of clusters per plant (NCP), number of fruits per cluster (NFC), fruit weight (FW), fruit length (FL), fruit circumference (FC), number of fruits per plant (NFP) and fruit size index (FSI). Fruit yield of tomato was adjusted to $t \mathrm{ha}^{-1}$ using the following formula: Fruit yield $\left(\mathrm{t} \mathrm{ha}^{-1}\right)=$ fruit yield per plot $(\mathrm{kg}) \times 10,000 /$ plot area $\left(\mathrm{m}^{2}\right) \times 1,000$.

\section{Statistical analysis}

The data was subjected to analysis of variance (ANOVA) using PROC GLM in SAS (SAS Institute, 2010) . Means were separated using Fisher's least significant difference (LSD) test $(\mathrm{P}<0.05)$. A rank summation index (RSI) (Mulumba and Mock, 1978) was constructed to create the aggregate trait by ranking accessions with regard to high fruit weight, fruit yield, improved agronomics, nutritional and physicochemical traits. Ranks were summed for each accession to select the top five. Pearson's correlation analysis was done to determine associations among all traits measured with SAS. Hierarchical cluster analysis was performed using SAS PROC CLUSTER based on centroid distance and a dendrogram constructed by PROC TREE in SAS to identify divergent groups. To identify patterns of morphological variation, principal component analysis (PCA) was conducted. Those PCs with Eigen values $>1$ were selected (Jeffers, 1967). The PCA analysis reduces dimensions of a multivariate data to a few principal axes, generates an Eigen vector for each axis and produces component scores for characters (Sneath and Sokal, 1973).

\section{Results}

The ANOVA produced significant mean squares for all agronomic, nutritional and physicochemical traits of the tomato accessions indicating genetic variations for all measured traits (Table 2). The coefficient of variation (CV) used to measure the precision of the experiment indicated the data was reliable (Table 2). Phenotypic variation in the biological growth stages of tomato accessions revealed that LA4113 was tallest and LA2641 shortest (Table 3). The most fruits per cluster were observed for accession LA0103 and least for LA1041. The most fruits per plant were observed for accession LA0411, the least for LA4138. For fruit yield related 
Table 2. Mean squares from analysis of variance of agronomic, nutritional andphysicochemical traits of wild tomato accessions

\begin{tabular}{|c|c|c|c|c|c|c|c|c|c|}
\hline Source & $\mathrm{df}$ & NLM & $\begin{array}{l}\mathrm{PH} \\
(\mathrm{cm})\end{array}$ & NCP & NFC & FW (g) & $\begin{array}{l}\text { Fruit yield } \\
\text { (t/ha) }\end{array}$ & $\mathrm{FL}(\mathrm{cm})$ & FC $(\mathrm{cm}$ \\
\hline Replication & 2 & 752.03 & 65.89 & 4.58 & $31.57^{* *}$ & $57571.79^{* *}$ & $1.44^{* *}$ & $0.19^{*}$ & 0.15 \\
\hline Accessions & 12 & $3254.65^{* *}$ & ${ }^{*} 148.54^{* * *}$ & $31.89^{* *}$ & $28.52^{* * *}$ & $24458.12^{*}$ & $0.61^{*}$ & $0.37^{* * *}$ & $0.65^{* * *}$ \\
\hline Error & 24 & 408.16 & 37.18 & 10.53 & 4.80 & 11010.68 & 0.28 & 0.05 & 0.11 \\
\hline $\mathrm{CV}$ & & 17.77 & 13.67 & 33.11 & 29.22 & 68.32 & 68.32 & 13.20 & 19.79 \\
\hline Source & $\mathrm{df}$ & NFP & FSI & $\begin{array}{l}\text { VIT C } \\
(\mathrm{mg} / 100 \mathrm{~g})\end{array}$ & $\begin{array}{l}\text { TSS }\left({ }^{o} \text { Brix }\right) \\
(\mathrm{g} / 100 \mathrm{~g})\end{array}$ & $\begin{array}{l}\text { TA } \\
(\mathrm{g} / 100 \mathrm{~g})\end{array}$ & $\begin{array}{l}\text { Fruit juice } \\
\text { pH }\end{array}$ & $\begin{array}{l}\text { Lycopene } \\
\text { (mg/100 g) }\end{array}$ & \\
\hline Replication & 2 & 1381.87 & 0.02 & 2.3 & 0.0004 & 0.0003 & 0.003 & 0.51 & \\
\hline Accessions & 12 & $4605.24^{* *}$ & $* 0.08^{* * *}$ & $147.40^{* * *}$ & $0.51^{* * *}$ & $0.17^{* * *}$ & $0.08^{* * *}$ & $106.12^{* * *}$ & \\
\hline Error & 24 & 841.79 & 0.02 & 2.54 & 0.03 & 0.002 & 0.002 & 0.31 & \\
\hline CV & & 42.25 & 12.37 & 4.94 & 4.14 & 4.74 & 0.95 & 2.38 & \\
\hline
\end{tabular}

$*, * * * * *$ Significant at $0.05,0.01$ and 0.001 probability levels, respectively.

$\mathrm{CV}=$ Coefficient of variation, $\mathrm{NLM}=$ Number of leaves at maturity, $\mathrm{PH}=$ Plant height at maturity, $\mathrm{NCP}=$ Number of cluster per plant, $\mathrm{NFC}=$ Number of fruits per cluster, FW $=$ Fruit weight, FL $=$ Fruit length, FC $=$ Fruit circumference, NFP $=$ Number of fruits per plant, FSI $=$ Fruit size index, VIT C $=$ Vitamin C, TSS $=$ Total soluble solids, TA $=$ Titratable acidity.

traits, tomato accession LA0130 had the heaviest fruit and most fruit yield, LA1293 had the lowest fruit weight and least fruit yield. Accession LA0411 had the highest concentration of vitamin C. LA1028 had the highest levels of total soluble solids while accessions LA4113, LA4138, LA1041 had the lowest levels. Accessions LA1208 and LA4133 had the lowest titratable acidity, LA2641, LA1293 and LA0130 had the lowest fruit juice $\mathrm{pH}$. Lycopene content was highest in tomato accession LA0130 and lowest in LA1208 (Table 3).

Based on a rank summation index (RSI) of 13 accessions, LA0130 was identified as best performing among all tested accessions, with the best fruit yield performance, desirable agronomic, nutritional and physicochemical traits. Tomato accession LA0130 was characterized by moderate plant height, highest number of fruits per cluster, fruit weight and fruit yield (Table 3). Accession LA0130 also had the highest titratable acidity and lycopene content, but moderate fruit juice $\mathrm{pH}$ (Table 4).

Pearson's correlation coefficient was calculated to determine associations among traits and showed variation for some trait combinations (Table 5). Fruit yield was significantly positively correlated with fruit weight coupled with a significant negative correlation with number of leaves at maturity. Fruit size index was significantly negatively correlated with fruit circumference and significantly positively correlated with vitamin C content. Total soluble solid was significantly positively correlated with number of leaves at maturity and vitamin C content. Titratable acidity was significantly positively correlated with number of fruit per plants and total soluble solid. Fruit juice $\mathrm{pH}$ was significantly negatively correlated with number of fruit per plant, total soluble solid and titratable acidity. Lycopene content was positively significantly correlated with vitamin C content and titratable acidity.

All agronomic traits, nutritional and physicochemical parameters measured which showed significant vari- ations were adopted to construct a hierarchical cluster based on the centroid distances among the 13 tomato accessions as in Figure 1. Cluster analysis differentiated the accessions into 4 distinct groups, where LA0130 differed from the other three groups. Cluster I consisted of five accessions, cluster II had four accessions, and clusters III and cluster IV had three and one accessions, respectively indicating variation among the accessions.

Additionally, contribution of each measured trait to the total variation within the accession was further determined through Principal Component Analysis (PCA) based on correlation matrix of the variables. The Scree plot of the PCA indicated six eigenvalues corresponding to the entire percent variance with eigenvalues $>1$. PCA1 accounted for about $22 \%$ of variation, PCA2 for $19 \%$, PCA3 for $15 \%$, PCA4 for $11 \%$, PCA5 for $10 \%$ and PCA6 for $6 \%$ (Table 6). The first principal component axis (PCA1) was mainly loaded positively by fruit yield, fruit yield related traits and titratable acidity. In PCA2 traits which had positive contribution were number of leaves at maturity, plant height at maturity, titratable acidity and lycopene. Fruit length, fruit circumference, total soluble solids and lycopene had positive contributions in PCA3. In PCA4 plant height at maturity, number of clusters per plant, fruit weight, fruit yield and fruit juice $\mathrm{pH}$ had positive contributions were. In PCA5 number of clusters per plant, number of fruits per cluster, fruit length, fruit circumference and total soluble solids had positive contributions. In PCA6 traits which had positive contributions were fruit length, fruit size index and Vitamin C content.

\section{Discussion}

Significant phenotypic variations among the accessions for all agronomic, nutritional and physicochemical traits validate availability of genetic diversity in the collection from the C.M. Rick Tomato Genetics 
Table 3. Mean ranking of agronomic traits of wild tomato accessions evaluated under the rainforest agro-ecology zone in Nigeria

\begin{tabular}{|c|c|c|c|c|c|c|c|c|c|c|c|c|}
\hline $\mathrm{S} / \mathrm{N}$ & Accession & $\begin{array}{l}\mathrm{PH} \\
(\mathrm{cm})\end{array}$ & NFC & NFP & FW (g) & $\begin{array}{l}\text { Fruit yield } \\
\text { (t/ha) }\end{array}$ & NLM & NCP & $\begin{array}{l}\text { FL } \\
(\mathrm{cm})\end{array}$ & $\begin{array}{l}\text { FC } \\
(\mathrm{cm})\end{array}$ & FSI & RSI \\
\hline 1 & LA0130 & 44.14 & 11.72 & 95.42 & 380.00 & 1.90 & 99.67 & 9.72 & 2.30 & 2.05 & 1.15 & 30 \\
\hline 2 & LA0411 & 52.97 & 8.64 & 143.78 & 113.33 & 0.57 & 137.67 & 9.78 & 1.22 & 1.17 & 1.05 & 51 \\
\hline 3 & LA1136 & 45.22 & 8.50 & 79.33 & 236.67 & 1.18 & 109.67 & 8.44 & 1.33 & 1.20 & 1.13 & 63 \\
\hline 4 & LA2641 & 29.64 & 10.94 & 106.72 & 140.00 & 0.70 & 96.00 & 7.28 & 1.67 & 1.40 & 1.19 & 65 \\
\hline 5 & LA0103 & 48.39 & 10.20 & 86.23 & 143.33 & 0.72 & 108.00 & 18.39 & 1.85 & 1.90 & 0.98 & 67 \\
\hline 6 & LA1272 & 35.96 & 9.39 & 94.50 & 156.67 & 0.78 & 107.00 & 7.73 & 1.60 & 1.90 & 0.86 & 69 \\
\hline 7 & LA1208 & 39.74 & 4.28 & 28.95 & 220.00 & 1.10 & 49.00 & 8.55 & 1.50 & 2.27 & 0.67 & 71 \\
\hline 8 & LA1028 & 46.29 & 5.67 & 28.83 & 93.33 & 0.47 & 171.67 & 8.89 & 2.35 & 2.79 & 0.84 & 79 \\
\hline 9 & LA1293 & 50.92 & 6.34 & 95.72 & 40.00 & 0.20 & 145.00 & 10.11 & 1.38 & 1.45 & 0.99 & 80 \\
\hline 10 & LA4115 & 44.96 & 3.95 & 27.94 & 200.00 & 1.00 & 138.33 & 9.39 & 1.58 & 1.67 & 0.95 & 83 \\
\hline 11 & LA4138 & 40.85 & 3.67 & 20.72 & 90.00 & 0.45 & 138.33 & 7.16 & 1.78 & 1.37 & 1.31 & 83 \\
\hline 12 & LA1041 & 44.91 & 3.33 & 30.50 & 130.00 & 0.65 & 68.00 & 7.17 & 1.71 & 1.69 & 1.02 & 84 \\
\hline \multirow[t]{7}{*}{13} & LA4113 & 56.00 & 10.89 & 53.98 & 53.33 & 0.27 & 110.00 & 14.78 & 1.32 & 1.40 & 0.95 & 85 \\
\hline & Minimum & 17.92 & 2.67 & 11.25 & 10.00 & 0.05 & 34.00 & 5.83 & 1.20 & 1.00 & 0.66 & \\
\hline & Maximum & 62.08 & 15.83 & 205.83 & 500.00 & 2.50 & 176.00 & 29.17 & 2.41 & 2.90 & 1.46 & \\
\hline & Mean of Top 5 & 44.07 & 10.00 & 102.30 & 202.67 & 1.01 & 110.20 & 10.72 & 1.67 & 1.54 & 1.10 & \\
\hline & Grand mean & 44.61 & 7.50 & 68.66 & 153.59 & 0.77 & 113.72 & 9.80 & 1.66 & 1.71 & 1.01 & \\
\hline & Sel. Differential (\%) & -1.22 & 33.32 & 48.98 & 31.95 & 31.95 & -3.09 & 9.41 & 0.78 & -9.83 & 9.40 & \\
\hline & LSD (5 \%) & 10.28 & 3.69 & 48.89 & 176.83 & 0.88 & 34.05 & 5.47 & 0.37 & 0.57 & 0.21 & \\
\hline
\end{tabular}

PH $=$ Plant height at maturity, NFC $=$ Number of fruits per cluster, NFP $=$ Number of fruits per plant, FW = Fruit weight, NLM $=$ Number of leaves at maturity $\mathrm{NCP}=$ Number of cluster per plant, $\mathrm{FL}=$ Fruit length, $\mathrm{FC}=$ Fruit circumference, FSI $=$ Fruit size index. RSI $=$ Rank Summation Index. Sel. Differential $=$ Selection differential is estimated as a proportion (\%) of mean of all accessions

Table 4. Ranking of the mean performance of nutritional and physicochemical parameters of wild tomato accessions evaluated under the rainforest agro-ecology zone in Nigeria

\begin{tabular}{|c|c|c|c|c|c|c|c|}
\hline $\mathrm{S} / \mathrm{N}$ & Accession & Vit C (mg/100 g) & TSS ( ${ }^{\circ}$ Brix) & TA $(g / 100 \mathrm{~g})$ & Fruit juice $\mathrm{pH}$ & Lycopene (mg/100 g) & RSI \\
\hline 1 & LA0130 & 42.46 & 4.50 & 1.38 & 4.85 & 32.54 & 30 \\
\hline 2 & LA0411 & 46.28 & 4.50 & 1.26 & 4.9 & 31.02 & 51 \\
\hline 3 & LA1136 & 29.21 & 3.75 & 0.76 & 5.3 & 24.42 & 63 \\
\hline 4 & LA2641 & 32.07 & 3.88 & 0.98 & 4.8 & 15.11 & 65 \\
\hline 5 & LA0103 & 33.63 & 3.75 & 0.74 & 5.15 & 21.57 & 67 \\
\hline 6 & LA1272 & 21.02 & 3.75 & 0.95 & 5.00 & 16.13 & 69 \\
\hline 7 & LA1208 & 26.01 & 4.00 & 0.63 & 5.30 & 13.43 & 71 \\
\hline 8 & LA1028 & 34.56 & 4.85 & 0.82 & 5.05 & 22.16 & 79 \\
\hline 9 & LA1293 & 25.53 & 4.50 & 1.31 & 4.85 & 26.16 & 80 \\
\hline 10 & LA4115 & 25.38 & 3.75 & 1.02 & 5.10 & 27.65 & 83 \\
\hline 11 & LA4138 & 40.21 & 3.50 & 0.70 & 5.05 & 26.51 & 83 \\
\hline 12 & LA1041 & 31.38 & 3.50 & 0.85 & 5.30 & 31.24 & 84 \\
\hline \multirow[t]{7}{*}{13} & LA4113 & 30.64 & 3.50 & 0.69 & 5.15 & 18.63 & 85 \\
\hline & Minimum & 20.90 & 3.25 & 0.6 & 4.80 & 12.64 & \\
\hline & Maximum & 46.29 & 5.20 & 1.39 & 5.30 & 32.81 & \\
\hline & Mean of Top 5 & 36.73 & 4.08 & 1.02 & 5.00 & 24.93 & \\
\hline & Grand mean & 32.18 & 3.98 & 0.93 & 5.06 & 23.58 & \\
\hline & Sel. Differential (\%) & 14.13 & 2.42 & 10.01 & -1.22 & 5.73 & \\
\hline & LSD (5 \%) & 2.95 & 0.31 & 0.08 & 0.09 & 1.04 & \\
\hline
\end{tabular}

VIT C $=$ Vitamin C, TSS $=$ Total soluble solids, TA $=$ Titratable acidity. RSI $=$ Rank Summation Index. Sel. Differential $=$ Selection differential is estimated as a proportion (\%) of mean of all accessions 
Table 5. Pearson's correlation coefficient ( $\mathrm{r}$ ) of agronomic, nutritional and physicochemical traits of wild tomato accessions evaluated under a rainforest agro-ecology in Nigeria

\begin{tabular}{|c|c|c|c|c|c|c|c|c|c|c|}
\hline & NLM & FW (g) & $\begin{array}{l}\text { Fruit yield } \\
\text { (t/ha) }\end{array}$ & $\mathrm{FC}(\mathrm{cm})$ & NFP & FSI & $\begin{array}{l}\text { VIT C } \\
(\mathrm{mg} / 100 \mathrm{~g})\end{array}$ & $\begin{array}{l}\text { TSS } \\
\left({ }^{o} \text { Brix }\right)\end{array}$ & $\begin{array}{l}\text { TA } \\
(\mathrm{g} / 100 \mathrm{~g})\end{array}$ & $\mathrm{pH}$ \\
\hline FW & $-0.32^{*}$ & & & & & & & & & \\
\hline $\begin{array}{l}\text { Fruit } \\
\text { yield }\end{array}$ & $-0.32^{*}$ & $1.00^{* * *}$ & & & & & & & & \\
\hline FC & 0.03 & 0.01 & 0.01 & & & & & & & \\
\hline NFP & -0.05 & 0.18 & 0.18 & $-0.34^{*}$ & & & & & & \\
\hline FSI & 0.18 & 0.05 & 0.05 & $-0.60^{* * *}$ & 0.18 & & & & & \\
\hline VIT C & 0.19 & 0.08 & 0.08 & -0.07 & 0.22 & $0.40^{*}$ & & & & \\
\hline TSS & $0.37^{*}$ & 0.08 & 0.08 & 0.30 & 0.30 & -0.10 & $0.38^{*}$ & & & \\
\hline TA & 0.24 & 0.15 & 0.15 & -0.08 & $0.50^{* * *}$ & 0.18 & 0.32 & $0.66^{* * *}$ & & \\
\hline $\mathrm{pH}$ & $-0.35^{*}$ & 0.04 & 0.04 & 0.03 & $-0.49^{* * *}$ & -0.21 & -0.31 & $-0.51^{* * *}$ & $-0.76^{* * *}$ & \\
\hline Lycopene & 0.27 & 0.15 & 0.15 & -0.14 & 0.10 & $0.35^{*}$ & $0.58^{* * *}$ & $0.32^{*}$ & $0.57^{* * *}$ & -0.14 \\
\hline
\end{tabular}

*, *** Significant at 0.05 and 0.001 probability levels, respectively.

NLM = Number of leaves at maturity, FW = Fruit weight, FC = Fruit circumference, NFP = Number of fruits per plant, FSI = Fruit size index, VIT $\mathrm{C}=$ Vitamin $\mathrm{C}$, TSS $=$ Total soluble solids, $\mathrm{TA}=$ Titratable acidity, $\mathrm{pH}=$ Fruit juice $\mathrm{pH}$.

Table 6. Eigenvalue, proportion of variability and estimated traits of wild tomato accessions contributing to first six principal components

\begin{tabular}{|c|c|c|c|c|c|c|}
\hline Traits & PC1 & PC2 & PC3 & PC4 & PC5 & PC6 \\
\hline NLM & -0.08 & 0.31 & 0.20 & -0.04 & 0.00 & -0.07 \\
\hline $\mathrm{PH}(\mathrm{cm})$ & -0.16 & 0.34 & 0.06 & 0.32 & -0.07 & -0.20 \\
\hline NCP & -0.08 & 0.18 & -0.12 & 0.48 & 0.21 & 0.13 \\
\hline NFC & 0.29 & 0.07 & -0.28 & 0.12 & 0.24 & 0.15 \\
\hline FW (g) & 0.37 & -0.26 & 0.06 & 0.27 & -0.06 & -0.08 \\
\hline Fruit yield (t/ha) & 0.37 & -0.2 & 0.06 & 0.27 & -0.06 & -0.08 \\
\hline $\mathrm{FL}(\mathrm{cm})$ & 0.03 & -0.05 & 0.41 & 0.07 & 0.30 & 0.51 \\
\hline $\mathrm{FC}(\mathrm{cm})$ & -0.09 & -0.13 & 0.32 & 0.09 & 0.54 & 0.09 \\
\hline NFP & 0.32 & 0.22 & -0.21 & -0.05 & 0.06 & -0.08 \\
\hline FSI & 0.14 & 0.11 & 0.03 & -0.10 & -0.48 & 0.53 \\
\hline VIT C (mg/100 g) & 0.16 & 0.25 & 0.22 & 0.16 & -0.16 & 0.33 \\
\hline TSS ( ${ }^{o}$ Brix) & 0.19 & 0.21 & 0.31 & -0.11 & 0.24 & -0.29 \\
\hline TA $(g / 100 \mathrm{~g})$ & 0.30 & 0.26 & 0.20 & -0.18 & 0.02 & -0.24 \\
\hline Fruit juice pH & -0.24 & -0.27 & -0.10 & 0.29 & -0.17 & -0.08 \\
\hline Lycopene (mg/100 g) & 0.13 & 0.19 & 0.34 & 0.12 & -0.34 & -0.11 \\
\hline Eigenvalue & 4.15 & 3.68 & 2.82 & 2.12 & 1.98 & 1.08 \\
\hline Proportion (\%) & 22 & 19 & 15 & 11 & 10 & 6 \\
\hline Cumulative (\%) & 21 & 41 & 56 & 67 & 78 & 83 \\
\hline
\end{tabular}

$\mathrm{NLM}=$ Number of leaves at maturity, $\mathrm{PH}=$ Plant height at maturity, NCP $=$ Number of cluster per plant, NFC $=$ Number of fruits per cluster, FW $=$ Fruit weight, FL $=$ Fruit length, FC $=$ Fruit circumference, NFP $=$ Number of fruits per plant, FSI $=$ Fruit size index, VIT C $=$ Vitamin C, TSS = Total soluble solids, TA = Titratable acidity. 


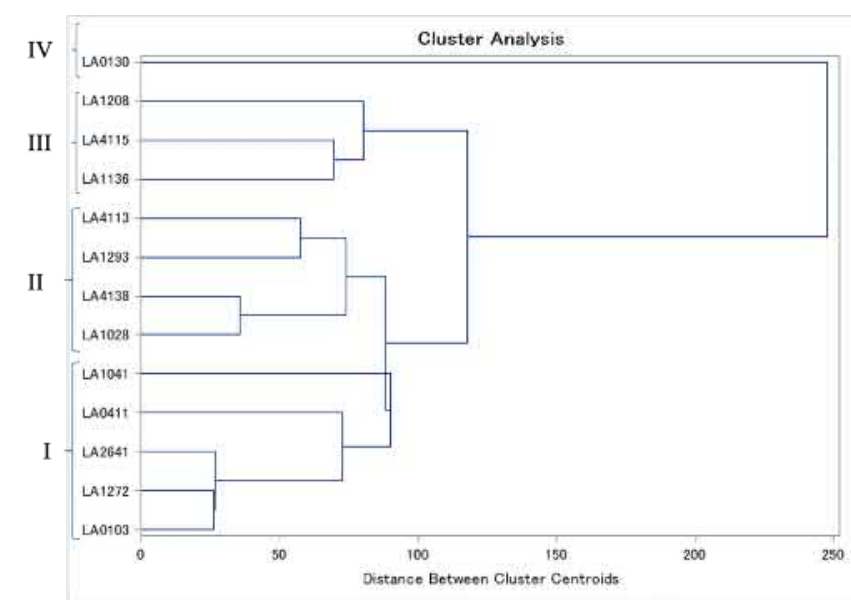

Figure 1. Dendrogram of 13 wild tomato accessions based onagronomic traits, nutritional and physicochemical parameters generated by centroid hierarchical cluster analysis

Resource Center (Chetelat, 2004, 2006). Previous research reported significant variations for agronomic traits for cultivated tomato varieties grown in various environments in Africa (Chernet and Zibelo, 2014; Shiberu, 2016; Regassa et al, 2016). This study indicates a wealth of genetic variability for fruit quality traits of wild tomato accessions. Accessions LA0411 and LA2641 had the highest number of fruit per plant which could be ascribed to genetic variation in flower abortion (Kanneh et al, 2017). Numbers of fruit per plant from this study were higher than the values reported by CeballosAguirre and Vallejo-Cabrera (2012), but similar with the report of Agong et al (2001). The mean performances for fruits per cluster and fruit weight in our study were higher than the results presented by CeballosAguirre and Vallejo-Cabrera (2012) who worked on wild tomato accessions from the Tomato Genetics Resources Center (TGRC), University of CaliforniaDavis. Disparities in the results from this study may be due to difference in the accessions evaluated, number of days before transplanting, agronomic practices used, and the environment.

Important quality traits that determine flavor, shelf life and market-related attributes of tomato are total soluble solids, fruit juice $\mathrm{pH}$, titratable acidity, lycopene and Vitamin C content. The quality of tomato fruit for industrial processing and paste production depends on a high value of total soluble solids. Total soluble solids recorded in this present study ranged from 3 to $5{ }^{\circ} \mathrm{Brix}$ which is comparable to the minimum value of total soluble solids ( $4.5^{\circ}$ Brix) reported by Campos et al (2006) but considered low for industrial tomatoes. Previous studies have reported a range from 4 to 6 'Brix for total soluble solids of tomato fruits (Alcántar et al, 1999; Cramer et al, 2001; Pascale et al, 2001). High total soluble solid increases tomato paste efficiency and must be between 5.0 and $6.5 \%$ in industrial tomatoes (Teka, 2013). The range of $4.80-5.30$ for tomato fruit juice $\mathrm{pH}$ reported in this study is considerably high. Tomato fruit juice $\mathrm{pH}$ values can vary from 4.25 to 4.78 and fruits with high $\mathrm{pH}$ values may not be recommended for fresh tomato consumption or industrial processing (Paulson and Stevens, 1974; Anthon et al, 2011; Rajae et al, 2018). A pH below 4.50 is desirable because it reduces proliferation of microorganisms and indicates quality (Mohammed et al, 1999; Tigist et al, 2013). However, the $\mathrm{pH}$ of ripe tomatoes may exceed 4.50 because a higher $\mathrm{pH}$ value is associated with flavor (Stevens, 1972). Titratable acidity in this study was higher than previously reported (George et al, 2004; Tigist et al, 2013; Rajae et al, 2018). Tomatoes are considered the main source of lycopene compounds and a major source of carotenoids in the human diet (Willcox et al, 2003). Lycopene imparts the red color to tomato and affects quality. The range for lycopene content reported in the literature is between $0.58-6.50 \mathrm{mg} 100 \mathrm{~g}^{-1}$ (Rickman et al, 2007; Saha et al, 2010), which is lower than reported in this study. The Vitamin C concentrations reported in this study for all accessions were higher than reported by Aoun et al (2013), but consistent with the range reported by Franke et al (2004) and Saha et al (2010). Our results show that wild tomato accessions contain significant antioxidants and may be useful for nutritional improvement in tomato breeding programmes (Tigchelaar, 1986) . All fruit quality and nutritional traits measured in this study reveal the value of the wild tomato accession as a source of useful alleles and their utilization as interesting donor parents in cultivar development.

Selection of the top outstanding five accessions with RSI may be useful as donor parent through intra and interspecific hybridization (Ghani et al, 2020) and may result in a significant increase in tomato fruit weight and fruit yield. This gain in fruit weight and yield could also be associated with improvement in number of fruits per cluster, number of fruits per plant, titratable acidity, lycopene content and fruit juice $\mathrm{pH}$. To improve breeding efficiency and selection indices in crop improvement, knowledge about correlation among traits is essential (Nzuve et al, 2014). Results from Pearson's correlation coefficients indicate that as tomato fruit yield increases, number of leaves at maturity decreases significantly. Selection based on fruit weight and reduction in number of leaves at maturity could lead to tomato fruit yield improvement. There were significant negative correlations between fruit juice $\mathrm{pH}$ and titratable acidity. This implies that increased fruit juice $\mathrm{pH}$ was accompanied by a decrease in titratable acidity and acid concentrations and is associated with maturity (Teka, 2013). Significant positive correlations between total soluble solids and titratable acidity in this study corroborate findings of Aoun et al (2013), and also indicated that plants with high sugar content have more free organic acids than plants with low sugar content (Saliba-Colombani et al, 2001; Georgelis, 2002; Getinet et al, 2008). With positive correlations, genes controlling these traits could be linked to, or be under control of, pleiotropic effects (Boćanski et al, 2009). Positive and/or negative desirable relationships among 
some agronomic, nutritional and physicochemical traits indicate that desirable genes in these wild accessions could be exploited in further breeding activities for cultivar improvement (Sujiprihati et al, 2003).

Furthermore, the wild tomato accessions were arranged in 4 clusters; with cluster IV appearing as the most phenotypically diverse. The best performing accession LA0130 in cluster IV has the highest number of fruits per cluster; highest fruit weight, fruit yield, vitamin C concentration, lycopene content, and moderate total soluble solids, titratable acidity and fruit juice $\mathrm{pH}$. This accession might harbor novel traits that are lacking in cultivated tomato and may be used as potential parent in tomato breeding to develop high yielding cultivars with desirable nutritional and physicochemical traits. The eigenvalue from PCA indicates importance of each principal component axis and its contribution to variability in traits of the tomato accessions. Fruit size index and vitamin $\mathrm{C}$ concentration play a role in explaining the variation but are less important than the first four factors.

\section{Conclusion}

This study identifies variability among the 13 wild tomato accessions evaluated. Accession LA0130 was outstanding for its unique attributes which included high number of fruits per cluster, fruit weight, fruit yield, total soluble solids, titratable acidity and lycopene content amongst others. Thus, this wild tomato accession may be considered promising to broaden the genetic variability for tomato improvement programmes. Consequently, this accession may be incorporated into the tomato breeding programme in the national institutes and could be used in hybridization for developing lines with desirable horticultural traits. Documentation of the agronomic, nutritional and physicochemical performance of the evaluated wild tomato accessions is informative for their utilization in breeding programmes. These results are useful for breeders working on the development and improvement of tomato, as desirable traits from these wild tomatoes can be transferred into the commercial tomato varieties suitable for the growth conditions in the rainforest agro-ecology zone of Nigeria and to boost production and diversity.

\section{Conflicts of Interest:}

The authors declare no conflict of interest.

\section{Acknowledgements}

The authors appreciate Mrs. Bola Bello for providing technical support during planting, field management, data collection and tomato harvesting.

\section{Author contributions}

D.O.I. designed the experiment. D.O.I., A.O.K. and R.T.F. executed the experiment. A.O.K. performed the data analysis. A.O.K. and D.O.I. wrote the manuscript. All the authors contributed to writing the article, read and approved its submission.

\section{References}

Agong, S. G., Schittenhelm, S., and Friedt, W. (2001). Genotypic variation of Kenyan tomato (Lycopersicon esculentum L.) germplasm. Journal of Food Technology in Africa 6(1), 13-17. url: https://dx.doi.org/10. 4314/jfta.v6i1.19277. doi: 10.4314/jfta.v6i1.19277

Ajayi, A. M. and Hassan, G. F. (2019). Response of selected tomato (Solanum lycopersicum L.) cultivars to on-field biotic stress. J. Agric. Crop Res. 7(3), 3846. doi: https://doi.org/10.33495/jacr \_v7i3.19.110

Alcántar, G. G., Villarreal, M. R., and Aguilar, A. S. (1999). Tomato growth (Lycopersion Esculentum Mill.), and nutrient utilization in response to varying fertigation programs. Acta Horticulturae 481，385-392. url: https://dx.doi.org/10.17660/ actahortic.1999.481.45. doi: 10.17660/actahortic. 1999.481.45

Álvaro Toledo and Burlingame, B. (2006). Biodiversity and nutrition: A common path toward global food security and sustainable development. Journal of Food Composition and Analysis 19(6-7), 477483. url: https://dx.doi.org/10.1016/j.jfca.2006.05. 001. doi: 10.1016/j.jfca.2006.05.001

Anthon, G. E., LeStrange, M., and Barrett, D. M. (2011). Changes in pH, acids, sugars and other quality parameters during extended vine holding of ripe processing tomatoes. Journal of the Science of Food and Agriculture 91(7), 1175-1181. url: https://dx.doi. org/10.1002/jsfa.4312. doi: 10.1002/jsfa.4312

Aoun, A. B., Lechiheb, B., Benyahya, L., and Ferchichi, A. (2013). Evaluation of fruit quality traits of traditional varieties of tomato (Solanum lycopersicum) grown in Tunisia. Afr. J. Food Sci. 7(10), 350-354. doi: https: //doi.org/10.5897/AJFS2013.1067

Bai, Y. and Lindhout, P. (2007). Domestication and Breeding of Tomatoes: What have We Gained and What Can We Gain in the Future? Annals of Botany 100(5), 1085-1094. url: https://dx.doi.org/10.1093/ aob/mcm150. doi: 10.1093/aob/mcm150

Bauchet, G. and Causse, M. (2012). Genetic diversity in tomato (Solanum lycopersicum) and its wild relatives. In Genetic diversity in plants, ed. Çalıs 133-162.

Beckles, D. M. (2012). Factors affecting the postharvest soluble solids and sugar content of tomato (Solanum lycopersicum L.) fruit. Postharvest Biology and Technology 63(1), 129-140. url: https://dx.doi.org/ 10.1016/j.postharvbio.2011.05.016. doi: 10.1016/j. postharvbio.2011.05.016

Bergougnoux, V. (2014). The history of tomato: From domestication to biopharming. Biotechnology Advances 32(1), 170-189. url: https://dx.doi.org/ 10.1016/j.biotechadv.2013.11.003. doi: 10.1016/j. biotechadv.2013.11.003

Blanca, J., Montero-Pau, J., Sauvage, C., Bauchet, G., Illa, E., Díez, M. J., Francis, D., Causse, M., van der 
Knaap, E., and Cañizares, J. (2015). Genomic variation in tomato, from wild ancestors to contemporary breeding accessions. BMC Genomics 16(1), 257-257. url: https://dx.doi.org/10.1186/s12864-015-1444-1. doi: 10.1186/s12864-015-1444-1

Boćanski, J., Srećkov, Z., and Nastasić, A. (2009). Genetic and phenotypic relationship between grain yield and components of grain yield of maize (Zea mays L.). Genetika 41(2), 145-154. url: https: //dx.doi.org/10.2298/gensr0902145b. doi: 10.2298/ gensr0902145b

Borja, A., Angosto, T., Capel, J., Abad, J., Anatasio, G., and Lozano, R. (1998). Intra and inter individual variations in components of tomato flavor for fresh consumption and wild lines. In Proceedings of XI Conference on Selection and Improvement of Horticultural Plants, 49-56.

Campos, C. A. B., Fernandes, P. D., Gheyi, H. R., Blanco, F. F., Goncalves, C. B., and Campos, S. A. F. (2006). Yield and fruit quality of industrial tomato under saline irrigation. Sci. Agr 63, 146-152.

Causse, M., Buret, M., Robini, K., and Verschave, P. (2003). Inheritance of Nutritional and Sensory Quality Traits in Fresh Market Tomato and Relation to Consumer Preferences. Journal of Food Science 68(7), 2342-2350. url: https://dx.doi.org/10.1111/ j.1365-2621.2003.tb05770.x. doi: 10.1111/j.13652621.2003.tb05770.x

Ceballos-Aguirre, N. and Vallejo-Cabrera, F. A. (2012). Evaluating the fruit production and quality of cherry tomato (Solanum lycopersicum var. cerasiforme). Rev. Fac. Nac. Agron. Medellín 65(2), 6593-6604. url: http://www.scielo.org.co/scielo.php?script $=$ sci $\_$arttext\&pid $=$S0304-28472012000200004\&lng $=$ en\&nrm $=$ iso.

Chen, J., Wang, H., Shen, H., Chai, M., Li, J., Qi, M., and Yang, W. (2009). Genetic variation in tomato populations from four breeding programs revealed by single nucleotide polymorphism and simple sequence repeat markers. Scientia Horticulturae 122(1), 616. url: https://dx.doi.org/10.1016/j.scienta.2009. 03.025. doi: 10.1016/j.scienta.2009.03.025

Chernet, S. and Zibelo, H. (2014). Evaluation of Tomato Varieties for Fruit Yield and Yield Components in Western Lowland of Tigray, Northern Ethiopia. International Journal of Agricultural Research 9(5), 259-264. url: https://dx.doi.org/10.3923/ijar.2014. 259.264. doi: 10.3923/ijar.2014.259.264

Chetelat, R. T. (2004). Revised list of wild species stocks. url: https://tgrc.ucdavis.edu/Wild\% 20species\%20stock\%20list-2013-v2.pdf.

Chetelat, R. T. (2006). Revised list of miscellaneous stocks. url: https://tgrc.ucdavis.edu/Miscstocks\%20list\%202015.pdf.

Chitarra, M. I. F. and Chitarra, A. B. (2005). Póscolheita de frutas e hortaliças: fisiologia e manuseio. (Post-harvest of fruits and vegetables: physiology and handling) 785-785, (in Portuguese).
Cramer, M. D., Oberholzer, J. A., and Combrink, N. J. (2001). The effect of supplementation of root zone dissolved inorganic carbon on fruit yield and quality of tomatoes (cv 'Daniella') grown with salinity. Scientia Horticulturae 89(4), 269-289. url: https://dx.doi. org/10.1016/s0304-4238(00)00243-0. doi: 10.1016/ s0304-4238(00)00243-0

Darwin, S. C., Knapp, S., and Peralta, I. E. (2003). Taxonomy of tomatoes in the Galápagos Islands: Native and introduced species ofSolanumsectionLycopersicon(Solanaceae). Systematics and Biodiversity 1(1), 29-53. url: https: //dx.doi.org/10.1017/s1477200003001026. doi: 10.1017/s1477200003001026

Domínguez, I., Ferreres, F., del Riquelme, F. P., Font, R., and Gil, M. I. (2012). Influence of preharvest application of fungicides on the postharvest quality of tomato (Solanum lycopersicum L.). Postharvest Biology and Technology 72, 1-10. url: https://dx. doi.org/10.1016/j.postharvbio.2012.04.010. doi: 10 . 1016/j.postharvbio.2012.04.010

FAO (2016). FAOSTAT. url: http://faostat.fao.org. accessed date: 2020-09-12

Franke, A. A., Custer, L. J., Arakaki, C., and Murphy, S. P. (2004). Vitamin C and flavonoid levels of fruits and vegetables consumed in Hawaii. Journal of Food Composition and Analysis 17(1), 1-35. url: https: //dx.doi.org/10.1016/s0889-1575(03)00066-8. doi: 10.1016/s0889-1575(03)00066-8

George, B., Kaur, C., Khurdiya, D. S., and Kapoor, H. C. (2004). Antioxidants in tomato (Lycopersium esculentum) as a function of genotype. Food Chemistry 84(1), 45-51. url: https://dx.doi.org/10. 1016/s0308-8146(03)00165-1. doi: 10.1016/s03088146(03)00165-1

Georgelis, N. (2002). High fruit sugar characterization, inheritance and linkage of molecular markers in tomato (Gainesville).

Getinet, H., Seyoum, T., and Woldetsadik, K. (2008). The effect of cultivar, maturity stage and storage environment on quality of tomatoes. Journal of Food Engineering 87(4), 467-478. url: https://dx.doi. org/10.1016/j.jfoodeng.2007.12.031. doi: 10.1016/j. jfoodeng.2007.12.031

Ghani, M. A., Abbas, M. M., Amjad, M., Ziaf, K., Ali, B., Shaheen, T., Awan, F. S., and Khan, A. N. (2020). Production and characterisation of tomato derived from interspecific hybridisation between cultivated tomato and its wild relatives. The Journal of Horticultural Science and Biotechnology 95(4), 506-520. url: https://dx.doi.org/10.1080/ 14620316.2019.1689182. doi: 10.1080/14620316. 2019.1689182

Hanson, P. M., Sitathani, K., Sadashiva, A. T., yu Yang, R., Graham, E., and Ledesma, D. (2007). Performance of Solanum habrochaites LA1777 introgression line hybrids for marketable tomato fruit yield in Asia. Euphytica 158(1-2), 167-178. url: https://dx.doi.org/ 
10.1007/s10681-007-9440-4. doi: 10.1007/s10681007-9440-4

Hanson, P. M., yu Yang, R., Wu, J., tzu Chen, J., Ledesma, D., Tsou, S. C., and Lee, T.-C. (2004). Variation for Antioxidant Activity and Antioxidants in Tomato. Journal of the American Society for Horticultural Science 129(5), 704-711. url: https://dx. doi.org/10.21273/jashs.129.5.0704. doi: 10.21273/ jashs.129.5.0704

Ilahy, R., Hdider, C., Lenucci, M. S., Tlili, I., and Dalessandro, G. (2011). Antioxidant activity and bioactive compound changes during fruit ripening of high-lycopene tomato cultivars. Journal of Food Composition and Analysis 24(4-5), 588595. url: https://dx.doi.org/10.1016/j.jfca.2010.11. 003. doi: $10.1016 /$ j.jfca.2010.11.003

International Plant Genetic Resources Institute (1996). Descriptors for tomato (Lycopersicon spp.) 1-44. url: $\quad$ https://www.bioversityinternational.org/elibrary/publications/detail/descriptors-for-tomatolycopersicon-spp/.

Jatoi, S. A., Fujimura, T., Yamanaka, S., Watanabe, J., and Watanabe, K. N. (2008). Potential loss of unique genetic diversity in tomato landraces by genetic colonization of modern cultivars at a non-center of origin. Plant Breeding 127(2), 189-196. url: https:// dx.doi.org/10.1111/j.1439-0523.2007.01446.x. doi: 10.1111/j.1439-0523.2007.01446.x

Jeffers, J. N. R. (1967). Two Case Studies in the Application of Principal Component Analysis. Applied Statistics 16(3), 225-225. url: https://dx.doi.org/10. 2307/2985919. doi: 10.2307/2985919

Kanneh, S. M., Quee, D. D., Ngegba, P. M., and Musa, P. D. (2017). Evaluation of Tomato (Solanum lycopersicum L.) Genotypes for Horticultural Characteristics on the Upland in Southern Sierra Leone. Journal of Agricultural Science 9(6), 213-213. url: https:// dx.doi.org/10.5539/jas.v9n6p213. doi: 10.5539/jas. v9n6p213

Miller, J. C. and Tanksley, S. D. (1990). RFLP analysis of phylogenetic relationships and genetic variation in the genus Lycopersicon. Theoretical and Applied Genetics 80(4), 437-448. url: https://dx.doi.org/10. 1007/bf00226743. doi: 10.1007/bf00226743

Mohammed, M., Wilson, L. A., and Gomes, P. I. (1999). Postharvest sensory and physiochemical attributes of processing and nonprocessing tomato cultivars. Journal of Food Quality 22(2), 167-182. url: https: //dx.doi.org/10.1111/j.1745-4557.1999.tb00549.x. doi: 10.1111/j.1745-4557.1999.tb00549.x

Mulumba, N. N. and Mock, J. J. (1978). Improvement of yield potential in the Eto Blanco maize (Zea mays L.) population by breeding for plant traits. Egypt. J. Genet. Cytol 7, 40-51.

Nnabude, P. C., Nweke, I. A., and Nsoanya, L. N. (2015). Response of three varieties of tomatoes (Lycopersicon esculentum) to liquid organic fertilizer (alfa life) and inorganic fertilizer (NPK 20:10:10) and for soil improvements. European Journal of Physical and Agricultural Sciences 3, 28-37.

Nowicki, M., Kozik, E. U., and Foolad, M. R. (2013). Late blight of tomato. In Translational Genomics for Crop Breeding, ed. Varshney, R. K. and Tuberosa, R. (John Wiley and Sons Ltd), 241-265.

Nzuve, F., Githiri, S., Mukunya, D. M., and Gethi, J. (2014). Genetic Variability and Correlation Studies of Grain Yield and Related Agronomic Traits in Maize. Journal of Agricultural Science 6(9), 166166. url: https://dx.doi.org/10.5539/jas.v6n9p166. doi: 10.5539/jas.v6n9p166

Olaniyi, J. O., Akanbi, W. B., Adejumo, T. A., and Akande, O. G. (2010). Growth, fruit yield and nutritional quality of tomato varieties. Afr. J. Food Sci 4, 398-402.

Onyia, V. N., Chukwudi, U. P., Ogwudu, V. C., Atugwu, A. I., Eze1, S. C., Ene, C. O., and Umeh, S. (2019). Evaluation of Tomato Genotypes Growth, Yield, and Shelf Life Enhancement in Nigeria. J. Agr. Sci .Tech 21, 143-152. url: https://jast.modares.ac.ir/article23-16444-en.pdf.

Pascale, S. D., Maggio, A., Fogliano, V., Ambrosino, P., and Ritieni, A. (2001). Irrigation with saline water improves carotenoids content and antioxidant activity of tomato. The Journal of Horticultural Science and Biotechnology 76(4), 447-453. url: https://dx. doi.org/10.1080/14620316.2001.11511392. doi: 10. 1080/14620316.2001.11511392

Paulson, K. N. and Stevens, M. A. (1974). Relationships among titratable acidity, $\mathrm{pH}$ and buffer composition of tomato fruits. Journal of Food Science 39(2), 354-357. url: https://dx.doi.org/10. 1111/j.1365-2621.1974.tb02893.x. doi: 10.1111/j. 1365-2621.1974.tb02893.x

Peixoto, J. V. M., Garcia, L. G. C., Nascimento, A. R., Moraes, E. R., Ferreira, T. A. P., Fernandes, M. R., and Pereira, V. D. A. (2018). Postharvest evaluation of tomato genotypes with dual purpose. Food Sci. Technol. 38, 255-262. doi: http://dx.doi.org/10. 1590/1678-457x.00217

Peralta, I. E., Spooner, D. M., Knapp, S., and Anderson, C. (2008). Taxonomy of wild tomatoes and their relatives (Solanum sect. Lycopersicoides, sect. Juglandifolia, sect. Lycopersicon; Solanaceae). Syst. Bot. Monogr 84(2), 1-186.

Rajae, A., Addi, M., Mingeot, D., Elamrani, A., Serghini, H. C., Mihamou, A., and Abid, M. (2018). Morphological, molecular, and physic-chemical characterization of traditional Moroccan tomato (Solanum Lycopersicum L.) genotypes. J. Biotech Res 9, 58-69. url: http: //www.btsjournals.com/assets/2018v9p58-69.pdf.

Regassa, D., Tigre, W., and Shiferaw, A. (2016). Tomato (Lycopersicon esculentum Mill.) varieties evaluation in Borana zone, Yabello district, Southern Ethiopia. Journal of Plant Breeding and Crop Science 8(10), 206210. doi: https://doi.org/10.5897/JPBCS2015.0543

Riahi, A., Hdider, C., Sanaa, M., Tarchoun, N., Kheder, M. B., and Guezal, I. (2009). Effect of conventional 
and organic production systems on the yield and quality of field tomato cultivars grown in Tunisia. Journal of the Science of Food and Agriculture 89(13), 2275-2282. url: https://dx.doi.org/10.1002/ jsfa.3720. doi: 10.1002/jsfa.3720

Rick, C. M. and Fobes, J. F. (1975). Allozyme Variation in the Cultivated Tomato and Closely Related Species. Bulletin of the Torrey Botanical Club 102(6), 376376. url: https://dx.doi.org/10.2307/2484764. doi: $10.2307 / 2484764$

Rickman, J. C., Barrett, D. M., and Bruhn, C. M. (2007). Nutritional comparison of fresh, frozen and canned fruits and vegetables. Part 1 . Vitamins $C$ and B and phenolic compounds. Journal of the Science of Food and Agriculture 87(6), 930-944. url: https://dx.doi. org/10.1002/jsfa.2825. doi: 10.1002/jsfa.2825

Rosales, M. A., Cervilla, L. M., Sánchez-Rodríguez, E., del Mar Rubio-Wilhelmi, M., Blasco, B., Ríos, J. J., Soriano, T., Castilla, N., Romero, L., and Ruiz, J. M. (2011). The effect of environmental conditions on nutritional quality of cherry tomato fruits: evaluation of two experimental Mediterranean greenhouses. Journal of the Science of Food and Agriculture 91(1), 152-162. url: https://dx.doi.org/10.1002/jsfa.4166. doi: $10.1002 /$ jsfa.4166

Rosales, M. A., Ruiz, J. M., Hernández, J., Soriano, T., Castilla, N., and Romero, L. (2006). Antioxidant content and ascorbate metabolism in cherry tomato exocarp in relation to temperature and solar radiation. Journal of the Science of Food and Agriculture 86(10), 1545-1551. url: https://dx.doi.org/10.1002/ jsfa.2546. doi: 10.1002/jsfa.2546

Saha, S., Hedau, N. K., Mahajan, V., Singh, G., Gupta, H. S., and Gahalain, A. (2010). Textural, nutritional and functional attributes in tomato genotypes for breeding better quality varieties. Journal of the Science of Food and Agriculture 90(2), 239-244. url: https://dx.doi.org/10.1002/jsfa.3802. doi: 10.1002/ jsfa.3802

Saliba-Colombani, V., Causse, M., Langlois, D., Philouze, J., and Buret, M. (2001). Genetic analysis of organoleptic quality in fresh market tomato. 1. Mapping QTLs for physical and chemical traits. Theoretical and Applied Genetics 102(2-3), 259-272. url: https://dx.doi.org/10.1007/s001220051643. doi: 10. 1007/s001220051643

SAS Institute (2010). Statistical Analysis Software (SAS) Release 9.3. url: https://support.sas.com/ documentation/93/.

Shiberu, T. (2016). Evaluation of improved tomato varieties (Lycopersicon esculentum Mill.) performance against major insect pests under open field and glasshouse conditions. International Journal of Research Studies in Agricultural Sciences 2(3), 1-7. doi: 10.20431/2454-6224.0203001

Singh, R. J. (2006). Genetic Resources, Chromosome Engineering, and Crop Improvement: Vegetable Crops, ed. Singh, R. J., volume 3 (CRC Press), 1-352.
Sneath, P. H. A. and Sokal, R. R. (1973). Numerical taxonomy. The principles and practice of numerical classification (San Francisco, CA: W.H Freeman), 1537.

Stevens, M. A. (1972). Relationships between components contributing to quality variation among tomato lines. J. Am. Soc. Hortic. Sci 97, 70-73.

Sujiprihati, S., Saleh, G. B., and Ali, E. S. (2003). Heritability, performance and correlation studies on single cross hybrids of tropical maize. Asian J. Plant Sci 2(1), 51-57. doi: 10.3923/ajps.2003.51.57

Teka, T. A. (2013). Analysis of the effect of maturity stage on the postharvest biochemical quality characteristics of tomato (Lycopersicon esculentum Mill.) fruit. Int. Res J Pharm. App Sci. 3(5), 180-186.

Tigchelaar, E. C. (1986). Tomato Breeding, ed. Basset, J., M., Ed., and Intercept, B. V. C. (Andover) 135-171.

Tigist, M., Workneh, T. S., and Woldetsadik, K. (2013). Effects of variety on the quality of tomato stored under ambient conditions. Journal of Food Science and Technology 50(3), 477-486. doi: 10.1007/s13197011-0378-0

Willcox, J. K., Catignani, G. L., and Lazarus, S. (2003). Tomatoes and Cardiovascular Health. Critical Reviews in Food Science and Nutrition 43(1), 1-18. url: https: //dx.doi.org/10.1080/10408690390826437. doi: 10. 1080/10408690390826437

Zuriaga, E., Blanca, J., and Nuez, F. (2009). Classification and phylogenetic relationships in Solanum section Lycopersicon based on AFLP and two nuclear gene sequences. Genetic Resources and Crop Evolution 56(5), 663-678. url: https://dx.doi.org/ 10.1007/s10722-008-9392-0. doi: 10.1007/s10722008-9392-0 